\title{
Sistem Informasi Career Development Center Fakultas Matematika Dan IImu Pengetahuan Alam Universitas Sebelas Maret Surakarta
}

\author{
Hanifah Hanun Nisa, Berliana Kusuma Riasti \\ Program Studi D3 Teknik Informatika, Sekolah Vokasi, Universitas Sebelas Maret \\ Email: hanifahhanun@student.uns.ac.id
}

\section{Info Artikel}

Kata Kunci :

career development, sistem informasi, lowongan pekerjaan, tes potensial akademik

Keywords :

career development,

information system, job vacancies, potential academic test

\section{Tanggal Artikel}

Dikirim : 6 April 2021

Diterima : 30 Mei 2021

\section{Abstrak}

Career Development merupakan salah satu cara formal yang digunakan sebuah perusahaan atau organisasi dalam memastikan orang-orang yang dibutuhkan akan tersedia dengan kualifikasi dan kelayakan yang sudah terpenuhi. Dalam sebuah lembaga pendidikan setingkat Universitas, pelayanan pengembangan karir difokuskan untuk mencarikan pekerjaan bagi mahsiswa ataupun alumni dari universitas tersebut. Terdapat salah satu metode yang dinilai lebih efektif dalam mengelola pengembangan karir sumberdaya manusia dalam suatu instansi yaitu menggunakan sistem informasi. Sistem informasi dapat digunakan secara online sehingga dapat diakses dimanasaja. Pelayanan pengembangan karir dengan menggunakan sistem informasi dapat memberikan pelayanan yang efektif dan efisien. Metode yang digunakan pada Sistem Informasi Career Development Center Fakultas Matematika dan IImu Pengetahaun Alam Universitas Sebelas Maret Surakarta meliputi observasi, pengumpulan data, analisis, perancangan sistem, implementasi dan uji coba. Hasil penelitian menunjukkan Sistem Informasi Career Development Center Fakultas Matematika dan IImu Pengetahuan Surakarta dapat melakukan pengajuan lowongan pekerjaan, penambahan lowongan pekerjaan, ujian soal Tes Potensial Akademik (TPA), dan menghitung hasil nilai ujian TPA dengan menggunakan rumus BAPPENAS. Cara kerja dari sistem tersebut yakni perusahaan menambahkan lowongan pekerjaan ke dalam sistem yang kemudian alumni akan menambahakan lamaran pekerjaan sesuai dengan lowongan pekerjaan yang akan dipilih, apabila alumni diterima oleh pihak perusahaan maka alumni akan dihubungi oleh pihak perusahaan sesuai dengan email ataupun nomor yang tertera di biodata alumni tersebut.

\section{Abstarct}

Career Development is a formal way that a company or organization uses to ensure that the people needed will be available with the qualifications and eligibility that have been met. In a university-level educational institution, career development services are focused on finding jobs for students or alumni from the university. There is one method that is considered more effective in managing career development of human resources in an institution, namely using an information system. Information systems can be used online so that they can be accessed anywhere. Career development services using information systems can provide effective and efficient services. The method used in the Career Development Center Information System, Faculty of Mathemathics and Natural Sciences, Sebelas Maret University Surakarta includes observation, data collection, analysis, system design, implementation and testing. The Career Development Center Information System of the Faculty of Mathematics and Science Surakarta has the ability to submit job vacancies, add job vacancies, test the Academic Potential Test (TPA), and calculate the results of the TPA exam score with BAPPENAS formula. The way this system works is that the company adds job vacancies to the system where alumni will add job applications according to the job vacancies to be selected, if the alumni are accepted by the company, the alumni will be contacted by the company according to the email or number listed on the biodata these alumni. 


\section{PENDAHULUAN}

Di era industrial saat ini, tuntutan untuk mendapatkan pekerjaan yang semakin tinggi dan persaingan Sumber Daya Manusia yang cukup ketat terkadang menyulitkan seseorang untuk mendapatkan suatu pekerjaan. Universitas Sebelas Maret Surakarta (UNS) memiliki Sistem Informasi 'Career Development Centre' berbasis web yang beralamatkan cdc.uns.ac.id memiliki tujuan untuk menjadi mediator antara para Alumni ataupun Mahasiswa dengan perusahaan / instansi yang sedang membutuhkan tenaga kerja. Namun, dikarenakan sistem tersebut masih bersifat global menjadikan masyarakat luar selain civitas akademika UNS dapat mengakses dam melamar pekerjaan melalui sistem tersebut. Sehingga persaingan alumni terutama fresh graduate dalam melamar pekerjaan melalui sistem tersebut dapat dikatakan cukup berat. Selain itu FMIPA UNS belum memiliki sistem informasi career development centre-nya sendiri. Oleh sebab itu penulis tertarik untuk menyusun tugas akhir dengan judul "Sistem Informasi Career Development Centre Fakultas Matematika dan IImu Pengetahuan Alam Universitas Sebelas Maret Surakarta Berbasis Web".

Penelitian pertama menurut [1] Hendrawan A, Joko D. Pengembangan sistem career centre untuk departemen konseling dan pengembangan karir (DKPK) universitas esa unggul. Jurnal IImu Komputer; 2013. Vol. 09. Dijelaskan bahwa tujuan dari penelitian tersebut adalah untuk membantu menangani masalah pendaftaran Career Centre untuk departemen Konseling dan Pengembangan Karir (DKPK) yang masih bersifat manual menjadi berbasis web/online.

Penelitian kedua menurut [2] Kusmiati, Herlinda. Pengembangan sistem informasi bursa lowongan pekerjaan divisi career center palcomtech berbasis WEB; 2015 Vol. 5, No. $1: 35$ - 49. Dijelaskan bahwa tujuan dari penelitian tersebut adalah untuk membantu para pencari kerja mendapatkan informasi tentang lowongan pekerjaan dan majikan dengan mudah dapat memberikan informasi yang diperlukan oleh pekerjanya.

Penelitian ketiga menurut [3] Hermawan J, Somantri M., dan Satoto K. Perancangan career development center undip berbasis web; 2012. Dijelaskan bahwa tujuan dari penelitian tersebut adalah untuk membuat sebuah sistem informasi berbasis web sebagaipusatinformasi lowongan pekerjaan bagi lulusan maupun mahasiswa aktif Universitas Diponegoro.

Penelitian keempat menurut [4] Stefanny V, Nurasia. Analisa dan perancangan aplikasi career development center pada stimik insan pembangunan; 2017. Jurnal IPSIKOM, Vol. 5. Dijelaskan bahwa tujuan dari penelitian tersebut adalah untuk membantu lulusan dari perguruan tinggi tersebut agar dapat memperoleh karir yang sesuai dengan bidang, minat dan bakat serta sesuai dengan jurusan yang sedang atau telah ditempuhnya.

Penelitian kelima menurut menurut [5] Syahputra A, Kusuma H. Pengembangan sistem cereer center untuk departemen konseling dan pengembangan karir di institut teknologi budi utomo; 2015. Jurnal BSI, Vol 3.No 2. Dijelaskan bahwa tujuan dari penelitian tersebut adalah untuk menangani masalah pendaftaran Career Centre untuk Departemen Konseling dan Pengembangan Karir yang masih bersifat konvesional menjadi berbasis web dan membantu mahasiswa untuk dapat mencari info lowongan pekerjaan dengan mendaftarkan diri di Career Centre secara online.

\section{METODE PENELITIAN}

Metodologi penelitian yang dilakukan dalam penelitian ini menggunakan metode waterfall [6]. Dimana metode waterfall merupakan proses pengembangan perangkat lunak yang sudah umum dilakukan. Disebut metode waterfall karena proses yang dilakukan yakni proses mengalir atau proses secara sistematis dari satu tahap ke tahap lainnya dalam mode turun ke bawah. [6] Metode waterfalldalam Sistem Informasi Career Development Fakultas Matematika dan IImu Pengetahuan Alam Universitas Sebelas Maret Surakarta dijelaskan sebagai berikut.

1. Persiapan

Dalam tahap persiapan, observasi dan pengumpukan data dilakukan oleh penulis dengan mengunjungi beberapa sumber dari website-website career centre yang terdapat pada kampus-beberapa universitas di Indonesia. Selain itu penulis juga melakukan observasi pada website job seeker yang tersebar di internet.

\section{Analisis dan Desain}

Setelah penulis mendapatkan data, maka pada tahap ini penulis melakukan Analisa menegenai apa saja kebutuhan sistem, membuat rancangan proses bisnis sistem dan rancangan model sistem, serta rancangan database dan rancangan desain antar muka yang dibutuhkan dalam pembuatan sistem tersebut

\section{Implementasi}


Pada tahap implementasi dilakukan pembuatan sistem berdasarkan kebutuhan yang sudah dirancang dan didesain pada tahap analisis.

4. Testing

Pada tahap testing, dilakukan pengujian terhadap sistem yang telah dibuat untuk mengevaluasi hasil dari sistem tersebut serta dilakukan perbaikan padda sistem apabila dalam sistem masih terdapat error.

\section{Penulisan Laporan}

Tahap penulisan laporan adalah tahap terakhir dalam pembuatan sistem, yaitu mendokumentasikan sistem informasi career development centre FMIPA yang telah dibuat.

\section{HASIL DAN PEMBAHASAN}

\subsection{Implementasi Sistem}

Implementasi Sistem Informasi Career Development Centre Fakultas Matematika Dan IImu Pengetahuan Alam Universitas Sebelas Maret adalah sebagai berikut.

\subsubsection{Halaman Admin}

\subsubsection{Implementasi Halaman Login Admin}

Halaman Login merupakan yang digunakan Admin untuk dapat masuk dan menggunakan sistem. Implementasi halaman login terdapat pada Gambar 1.

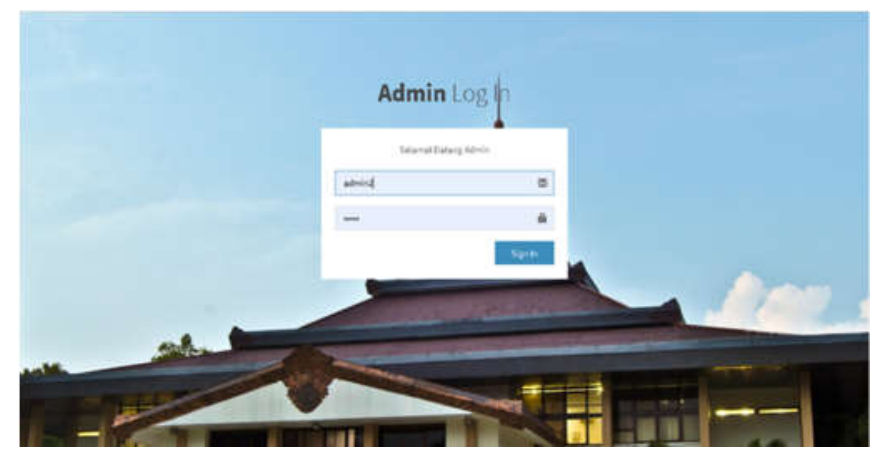

Gambar 1. Implementasi Halaman Login Admin

\subsubsection{Implementasi Halaman Beranda Backend Setelah Login}

Halaman beranda backend merupakan halama utama dari Admin yang ditampilkan pertama kali setelah Login. Implementasi halaman Beranda Backend Admin setelah login terdapat pada Gambar 2.

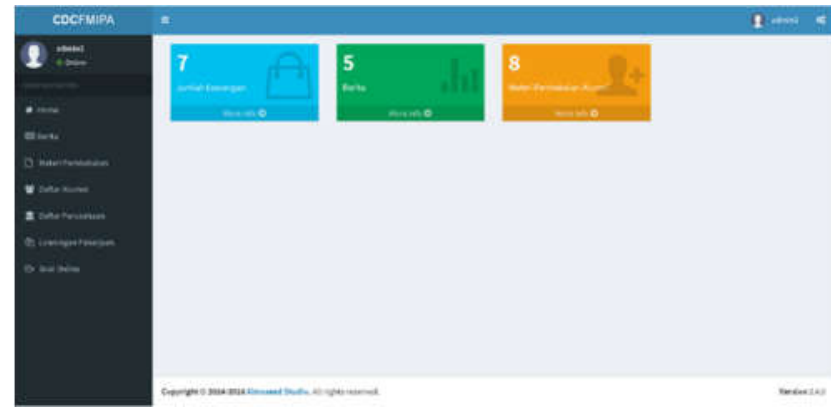

Gambar 2. Implementasi Halaman Beranda Backend Setelah Login

\subsubsection{Implementasi Halaman Lowongan Pekerjaan Admin}

Halaman Lowongan Pekerjaan menampilkan daftar lowongan pekerjaan yang telah diinputkan oleh perusahaan. Implementasi halaman lowongan pekerjaan admin terdapat pada Gambar 3. 


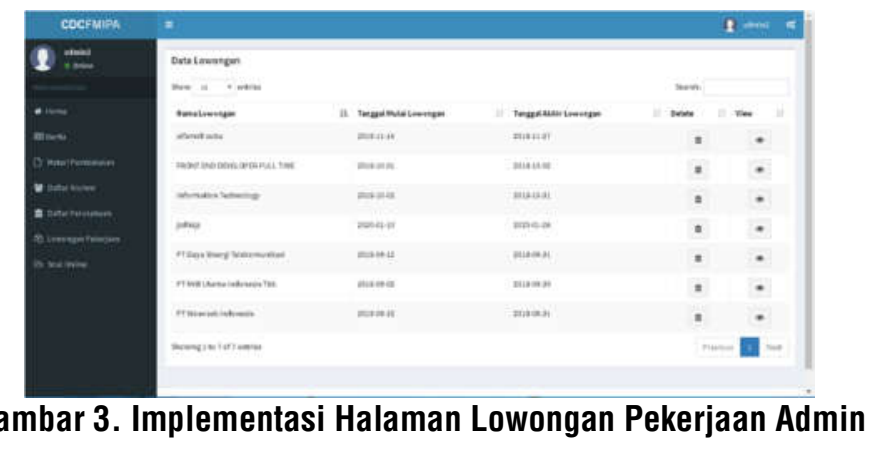

\subsubsection{Implementasi Halaman Detail Lowongan Pekerjaan Admin}

Halaman Detail Lowongan Pekerjaan menampilkan detail lowongan yang dipilih dan telah diunggah oleh perusahaan. Implementasi halaman detail lowongan pekerjaan admin terdapat pada Gambar 4.

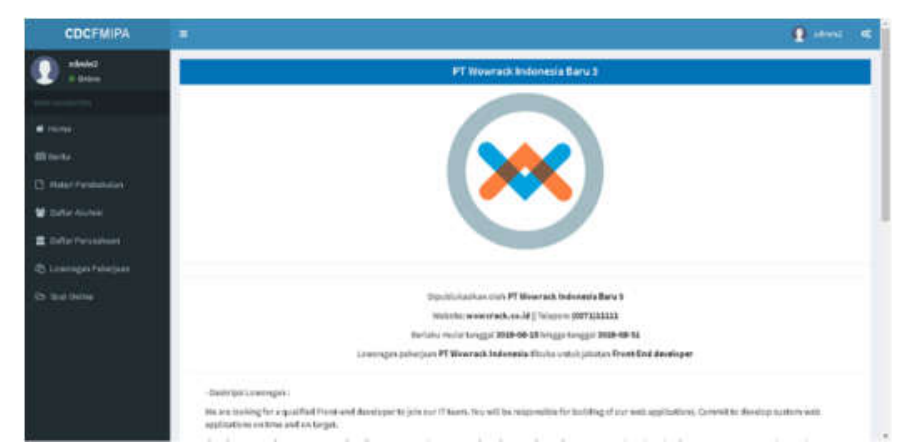

Gambar 4. Implementasi Halaman Detail Lowongan Pekerjaan Admin

\subsubsection{Implementasi Halaman Materi Pembekalan}

Halaman materi pembekalan menampilkan daftar Materi Pembekalan Alumni yang telah diinput oleh admin. Implementasi halaman materi pembekalan admin terdapat pada Gambar 5 .

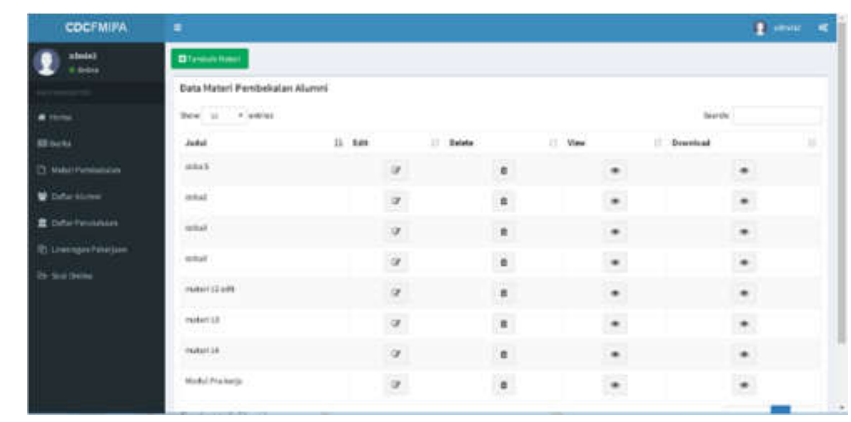

Gambar 5. Implementasi Halaman Materi Pembekalan

\subsubsection{Implementasi Halaman Detail Materi Admin}

Halaman Detail Materi menampilkan detail dari materi pembekalan yang telah dipilih. Implementasi halaman detail materi admin terdapat pada Gambar 6. 


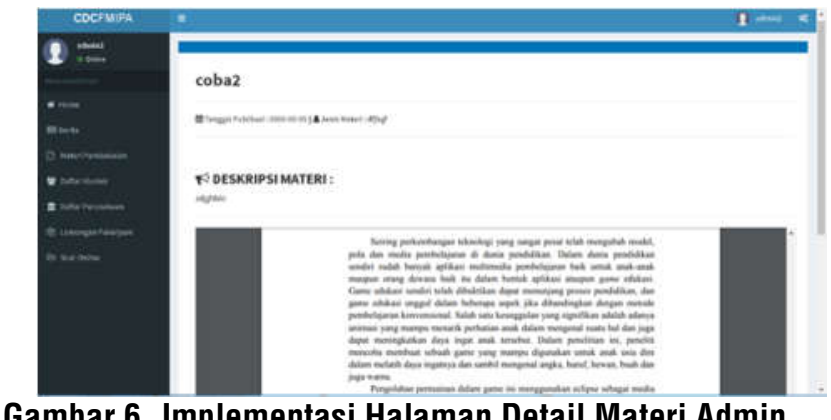

Gambar 6. Implementasi Halaman Detail Materi Admin

\subsubsection{Implementasi Halaman Berita}

Halaman Berita menampilkan daftar berita yang telah diinputkan oleh admin. Implementasi halaman berita admin terdapat pada Gambar 7.

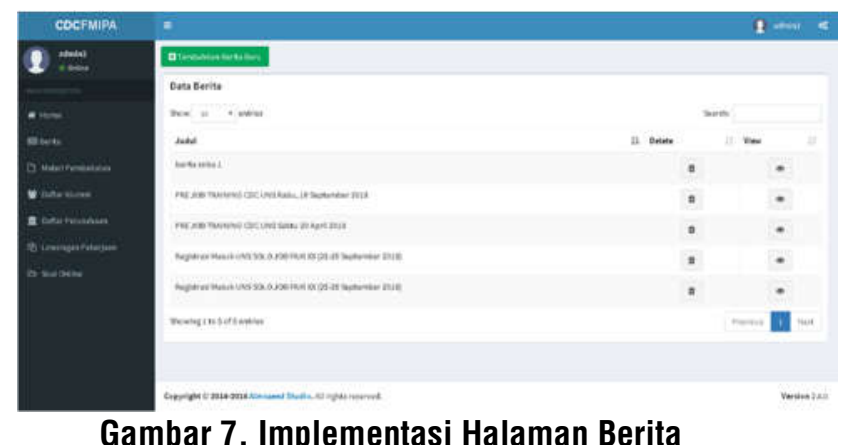

\subsubsection{Implementasi Halaman Detail Berita}

Halaman Detail Berita menampilkan detail dari berita yang telah dipilih. Implementasi halaman detail berita admin terdapat pada Gambar 8.

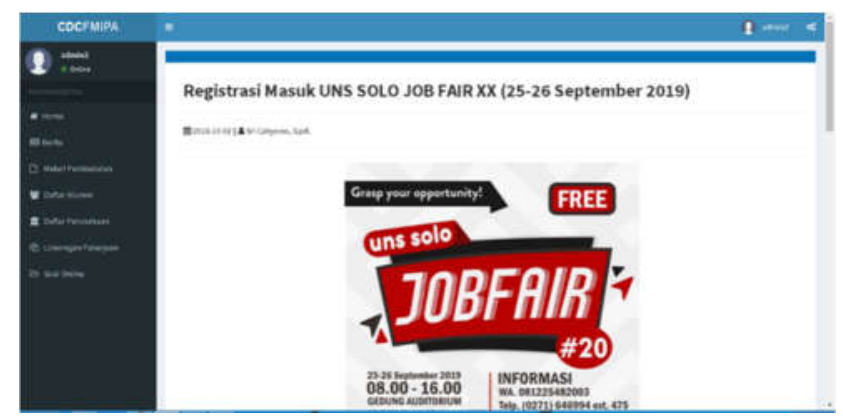

Gambar 8. Implementasi Halaman Detail Berita

\subsubsection{Implementasi Halaman Detail Alumni}

Halaman Detail Alumni menampilkan detail data diri alumni. Implementasi halaman detail alumni terdapat pada Gambar 9. 


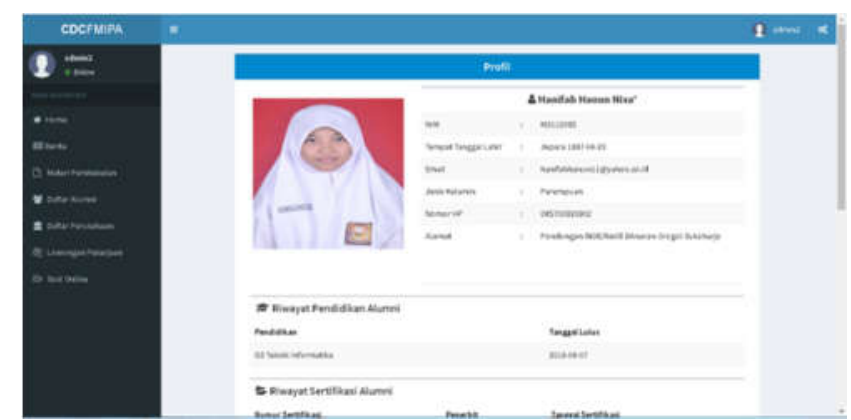

Gambar 9. Implementasi Halaman Detail Alumni

\subsubsection{Implementasi Halaman Detail Perusahaan}

Halaman Detail Perusahaan menampilkan detail dari data perusahaan. Implementasi halaman detail perusahaan terdapat pada Gambar 10.

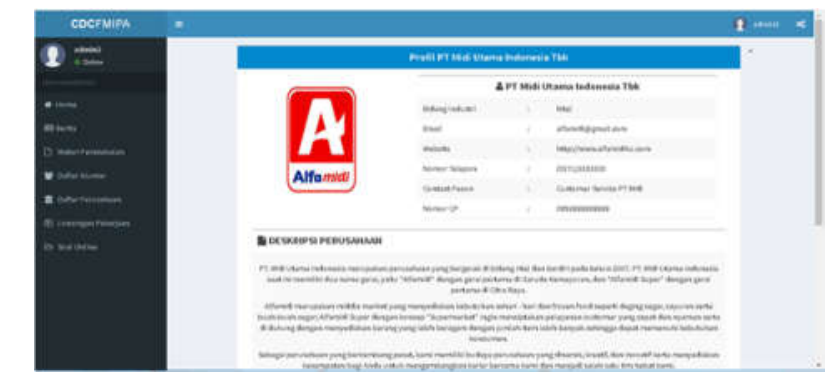

Gambar 10. Implementasi Halaman Detail Perusahaan

\subsubsection{Implementasi Halaman Soal Online}

Halaman soal online menampilkan berbagai jenis dari tipe soal yang akan digunakan oleh alumni untuk melakukan ujian online. Implementasi halaman soal online admin terdapat pada gambar 11.

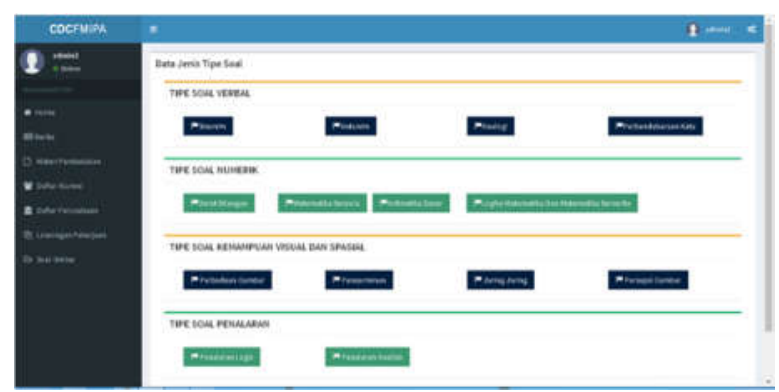

Gambar 11. Implementasi Halaman Detail Perusahaan

\subsubsection{Implementasi Halaman Jenis Soal}

Halaman jenis soal menampilkan daftar soal yang telah diinput oleh admin sesuai dengan jenis soal. Implementasi halaman jenis soal terdapat pada gambar 12.

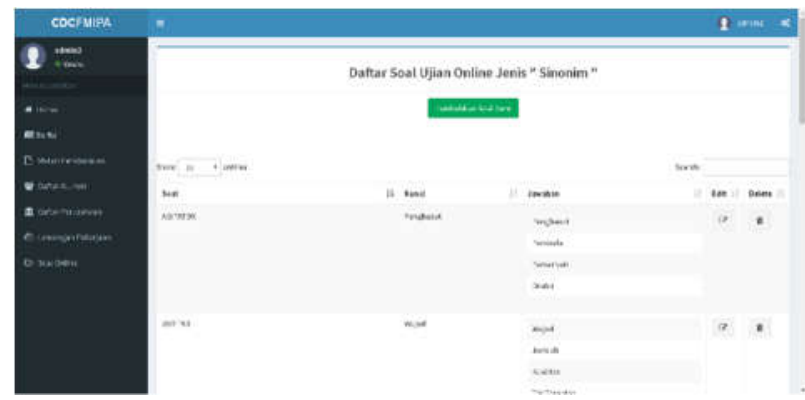

Gambar 12. Implementasi Halaman Jenis Soal 


\subsubsection{Halaman Perusahaan}

\subsubsection{Implementasi Halaman Login}

Halaman login merupakan halaman yang digunakan perusahaan untuk dapat masuk dan menggunakan sistem. Implementasi halaman login terdapat pada gambar 13.

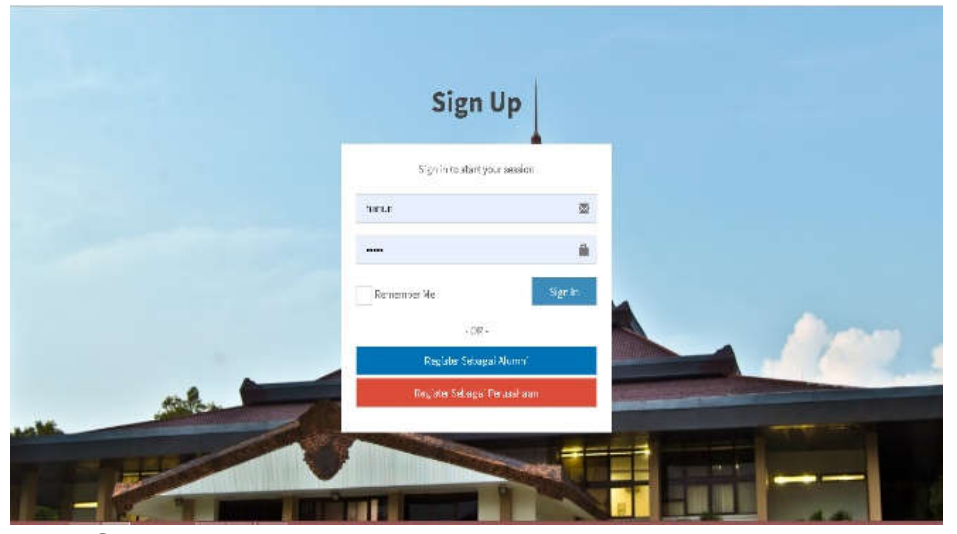

Gambar 13. Implementasi Halaman Login

\subsubsection{Implementasi Halaman Register}

Halaman register perusahaan merupakan halaman yang digunakan perusahaan untuk mendaftarkan akun baru. Implementasi halaman register perusahaan terdapat pada gambar 14.

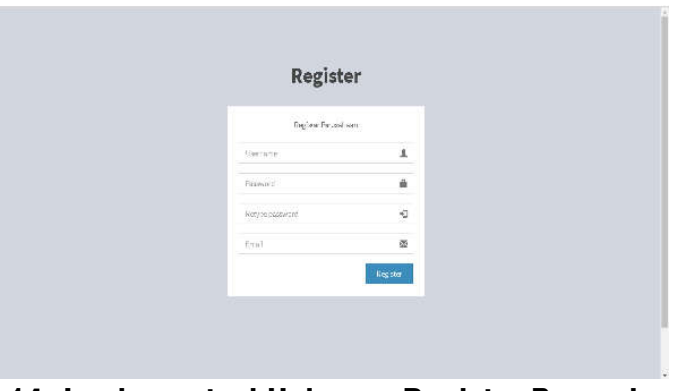

Gambar 14. Implementasi Halaman Register Perusahaan

\subsubsection{Implementasi Halaman Beranda}

Halaman beranda frontend perusahaan merupakan halaman utama yang ditampilkan pertama kali setelah login ke dalam sistem. Implementasi halaman beranda frontend perusahaan terdapat pada gambar 15.

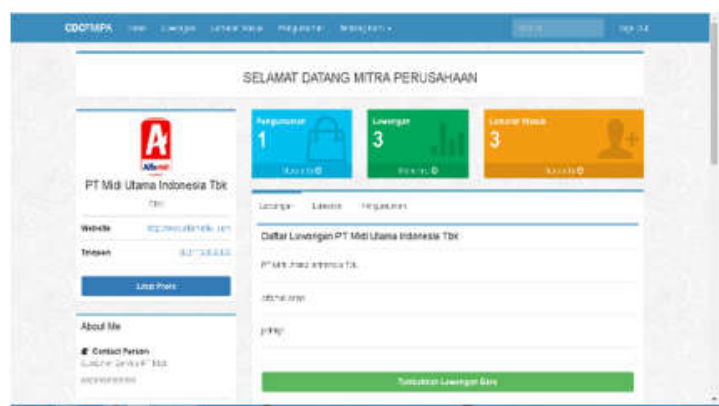

Gambar 15. Implementasi Halaman Beranda Perusahaan 


\subsubsection{Implementasi Halaman Lowongan}

Halaman lowongan menampilkan formulir untuk menambahkan lowongan baru. Implementasi halaman lowongan terdapat pada gambar 16 .

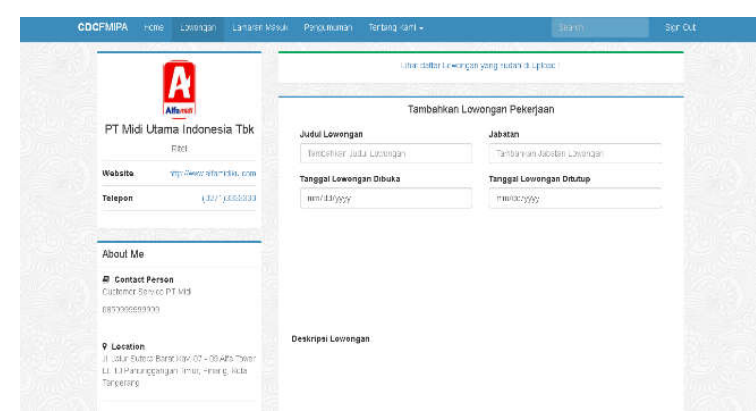

Gambar 16. Implementasi Halaman Lowongan

\subsubsection{Implementasi Halaman Pengumuman}

Halaman pengumuman menampilkan daftar pengumuman yang telah diinputkan oleh perusahaan serta menampilkan formulir untuk menambahkan pengumuman yang baru. Implementasi halaman pengumuman terdapat pada gambar 17 .

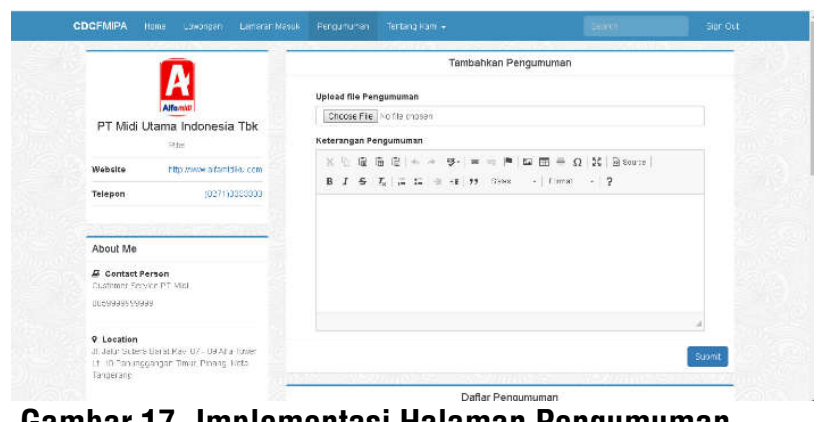

\section{Gambar 17. Implementasi Halaman Pengumuman}

\subsubsection{Implementasi Halaman Lamaran}

Halaman lamaran menampilkan daftar lamaran pekerjaan yang masuk dari alumni yang telah mendaftar lowongan dari perusahaan tersebut. Implementasi halaman lamaran terdapat pada gambar 18.

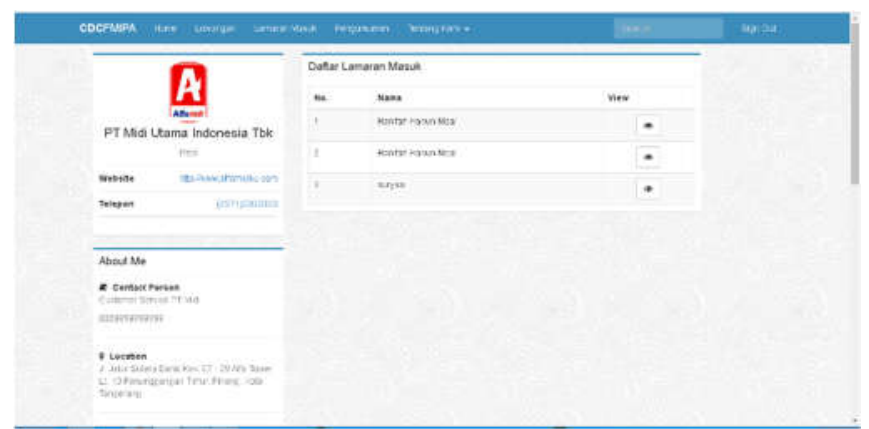

Gambar 18. Implementasi Halaman Lamaran

\subsubsection{Implementasi Halaman Profil Perusahaan}

Halaman profil perusahaan menampilkan data dari profil perusahaan. Implementasi halaman profil perusahaan terdapat pada gambar 19. 


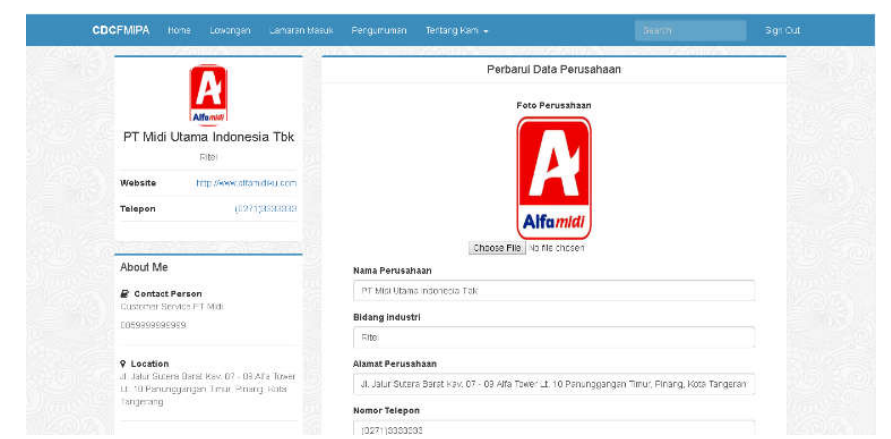

Gambar 19. Implementasi Halaman Profil Perusahaan

\subsubsection{Halaman Alumni}

\subsubsection{Implementasi Halaman Beranda Alumni}

Halaman beranda alumni merupakan halaman utama yang ditampilkan setelah login sebagai alumni. Implementasi halaman beranda frontend alumni terdapat pada gambar 20 .

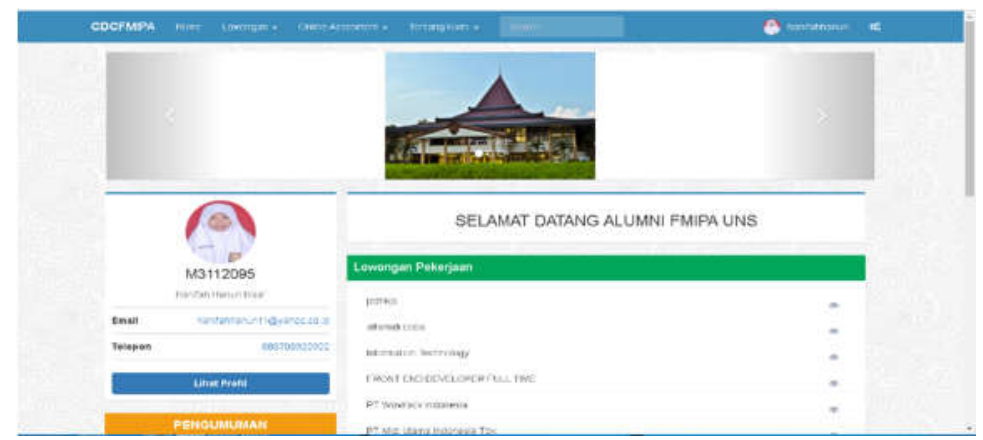

Gambar 20. Implementasi Halaman Beranda Alumni

\subsubsection{Implementasi Halaman Lowongan}

Halaman lowongan berisi daftar lowoangan yang telah diinput oleh berbagai perusahaan. serta daftar pengumuman lolos lowongan yang diinput oleh perusahaan. Implementasi halaman lowongan terdapat pada gambar 21.

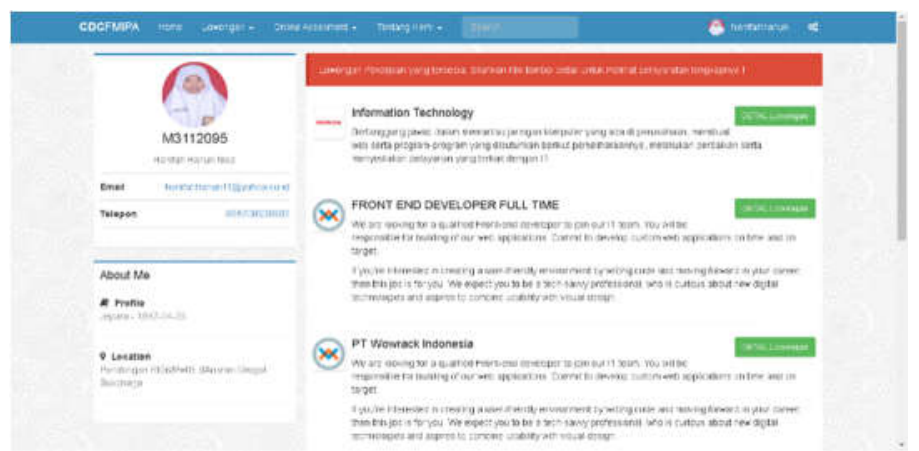

Gambar 21. Implementasi Halaman Lowongan

\subsubsection{Implementasi Halaman Detail Lowongan}

Halaman detail lowongan menampilkan detail dari lowongan pekerjaan yang telah dipilih. Halaman ini terdapat tombol untuk menambahkan lamaran pekerjaan apabila alumni ingin melamar lowongan tersebut. Implementasi halaman detail lowongan terdapat pada gambar 22. 


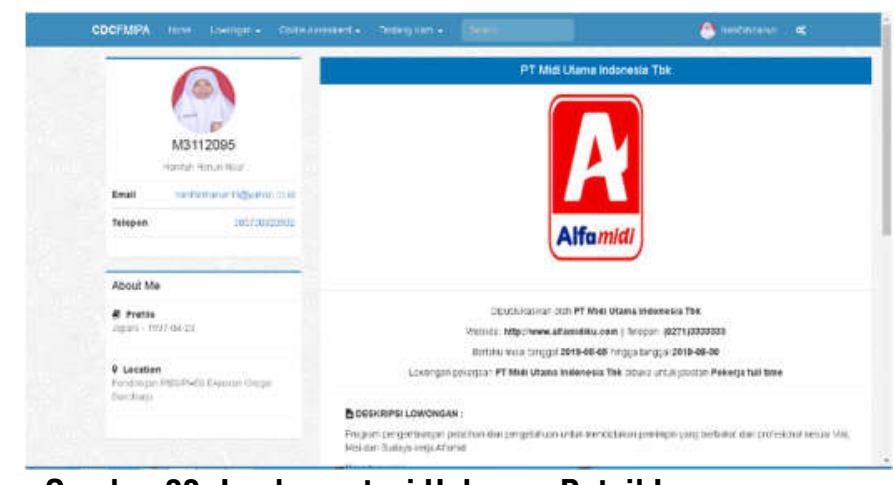

Gambar 22. Implementasi Halaman Detail Lowongan

\subsubsection{Implementasi Halaman Pengumuman}

Halaman Pengumuman Alumni merupakan halaman dimana alumni dapat mengunduh pengumuman dari lowongan pekerjaan yang telah diunggaholeh perusahaan. implementasi halaman pengumuman alumni terdapat pada gambar 23 .

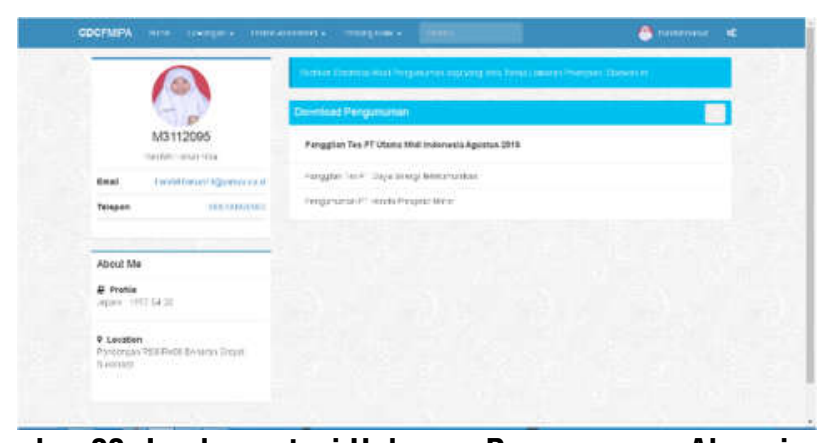

Gambar 23. Implementasi Halaman Pengumuman Alumni

\subsubsection{Implementasi Halaman Online Assessment}

Halaman Online Assessment merupakan halaman dimana alumni dapat mengerjakan Soal Tes Potensia Akademik. Implementasi halaman online assessment terdapat pada gambar 24.

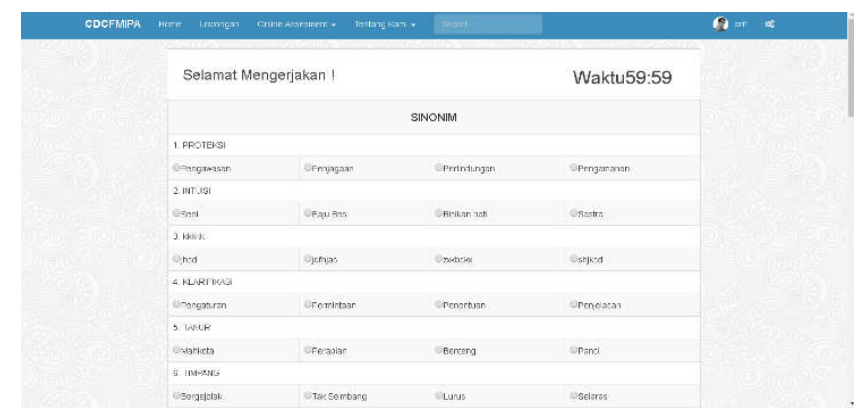

Gambar 24. Implementasi Halaman Online Assessment

\subsubsection{Implementasi Halaman Biodata Alumni}

Halaman biodata alumni menampilkan daftar dari keterangan data diri alumni. Implementasi halaman biodata alumni terdapat pada gambar 25 . 


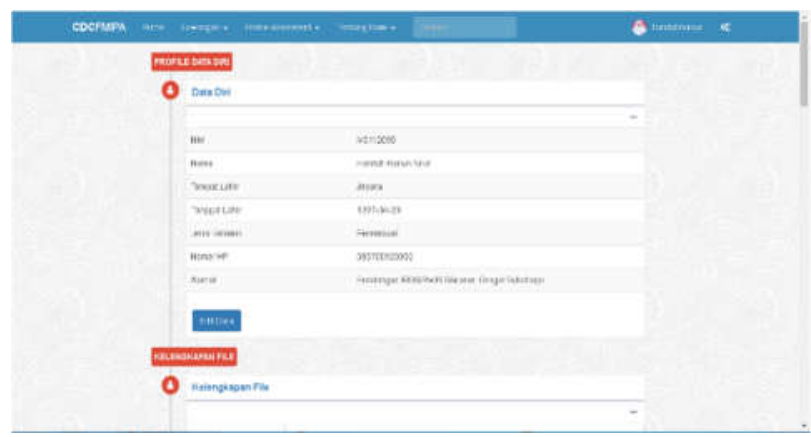

Gambar 25. Implementasi Halaman Biodata Alumni

\subsection{Pengujian Sistem}

Pengujian Sistem Informasi Career Development Berbasis Web menggunakan blackbox testing dapat dilihat pada Tabel 1.

Tabel 1. Tabel Pengujian

\begin{tabular}{|c|c|c|c|c|}
\hline No. & Skenario Diuji & Deskripsi & $\begin{array}{l}\text { Hasil yang } \\
\text { Diharapkan }\end{array}$ & $\begin{array}{l}\text { Hasil } \\
\text { Pengujian }\end{array}$ \\
\hline 1 & $\begin{array}{l}\text { Perusahaan memilih tombol } \\
\text { Register Perusahaan }\end{array}$ & $\begin{array}{l}\text { Sistem mampu } \\
\text { menambah data profil } \\
\text { perusahaan baru }\end{array}$ & $\begin{array}{l}\text { Sistem akan } \\
\text { menampilkan form } \\
\text { register perusahaan } \\
\text { yang harus diisi }\end{array}$ & Berhasil \\
\hline 2 & $\begin{array}{l}\text { Perusahaan Memilih tombol } \\
\text { Profil Perusahaan }\end{array}$ & $\begin{array}{lr}\text { Sistem } & \text { mampu } \\
\text { menampilkan } & \text { profil } \\
\text { perusahaan } & \end{array}$ & $\begin{array}{lr}\text { Sistem } & \text { akan } \\
\text { menampilkan } & \text { data } \\
\text { perusahaan. } & \end{array}$ & Berhasil \\
\hline 3 & $\begin{array}{l}\text { Perusahaan memilih tombol } \\
\text { Profil Perusahaan }\end{array}$ & $\begin{array}{lr}\text { Sistem } & \text { mampu } \\
\text { mengedit } & \text { profil } \\
\text { perusahaan } & \end{array}$ & $\begin{array}{l}\text { Sistem akan } \\
\text { menampilkan form } \\
\text { dimana perusahaan } \\
\text { dapat mengedit data } \\
\text { yang sebelumnya }\end{array}$ & Berhasil \\
\hline 4 & $\begin{array}{l}\text { Prusahaan atau Alumni } \\
\text { memilih tombol Register } \\
\text { Prusahaan sesuai dengan } \\
\text { role nya }\end{array}$ & $\begin{array}{l}\text { Prusahaan atau Alumni } \\
\text { memilih tombol } \\
\text { Register Prusahaan } \\
\text { sesuai dengan role nya }\end{array}$ & $\begin{array}{l}\text { Sistem } \\
\text { menampilkan } \\
\text { register. }\end{array}$ & Berhasil \\
\hline 5 & $\begin{array}{l}\text { Perusahaan memilih menu } \\
\text { lowongan kemudian } \\
\text { memilih tombol tambah } \\
\text { lowongan, lalu perusahaan } \\
\text { dapat mengisi formulir } \\
\text { lowongan tersebut. }\end{array}$ & $\begin{array}{l}\text { Sistem mampu } \\
\text { menambahakan } \\
\text { lowongan pekerjaan }\end{array}$ & 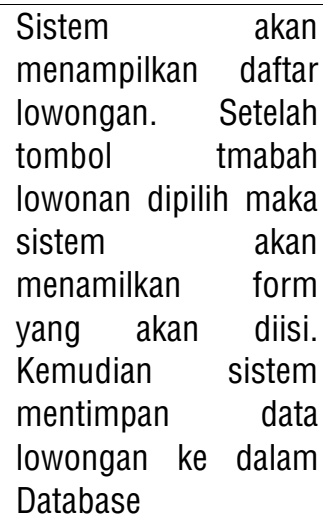 & Berhasil \\
\hline
\end{tabular}




\begin{tabular}{|c|c|c|c|c|}
\hline 6 & $\begin{array}{l}\text { Admin, Perusahaan, dan } \\
\text { Alumni memilih tombol view } \\
\text { dari daftar lowongan }\end{array}$ & $\begin{array}{l}\text { Sistem mampu } \\
\text { menampilkan lowongan } \\
\text { pekerjaan }\end{array}$ & $\begin{array}{lr}\text { Sistem } & \text { akan } \\
\text { menampilkan detail } \\
\text { dari } \quad \text { lowongan } \\
\text { pekerjaan. }\end{array}$ & Berhasil \\
\hline 7 & $\begin{array}{l}\text { Admin memilih tombol } \\
\text { delete dari lowongan yang } \\
\text { dipilih pada daftar } \\
\text { lowongan. }\end{array}$ & $\begin{array}{lr}\text { Sistem } & \text { mampu } \\
\text { menghapus } & \text { lowongan } \\
\text { pekerjaan } & \end{array}$ & $\begin{array}{lr}\text { Sistem akan } & \text { menghapus lowoga } \\
\text { yang tepilih dari } \\
\text { database. Kemudian } \\
\text { sistem } \\
\text { menampilkan daftar } \\
\text { lowongan }\end{array}$ & Berhasil \\
\hline 8 & $\begin{array}{l}\text { Admin atau Perusahaan } \\
\text { memilih tombol edit dari } \\
\text { lowongan yang telah dipilih } \\
\text { pada daftar lowongan. }\end{array}$ & $\begin{array}{l}\text { Sistem } \\
\text { mengedit } \\
\text { pekerjaan }\end{array}$ & \begin{tabular}{lr} 
Sistem & akan \\
menampilkan form \\
edit $\quad$ lowongan. \\
Setelah itu sistem \\
akan mengupdate \\
data lowongan baru di \\
\multicolumn{2}{l}{ database }
\end{tabular} & Berhasil \\
\hline 9 & $\begin{array}{l}\text { Alumni memilih salah satu } \\
\text { lowongan pekerjaan } \\
\text { kemudian alumni memilih } \\
\text { tombol Tambahkan } \\
\text { Lamaran Pekerjaan. }\end{array}$ & $\begin{array}{l}\text { Sistem mampu } \\
\text { menambahakan } \\
\text { lamaran pekerjaan }\end{array}$ & $\begin{array}{lr}\text { Sistem akan } & \text { menampilkan detail } \\
\text { lowongan. Kemudian } \\
\text { sistem akan } \\
\text { menampilkan form } \\
\text { lamaran pekerjaan. } \\
\text { Setelaj itu sistem akan } \\
\text { menambahkan ke } \\
\text { database. }\end{array}$ & Berhasil \\
\hline 10 & $\begin{array}{l}\text { Perusahaan memilih menu } \\
\text { lamaran pekerjaan }\end{array}$ & $\begin{array}{lr}\text { Sistem } & \text { mampu } \\
\text { menampilkan } & \text { lamaran } \\
\text { pekerjaan } & \end{array}$ & $\begin{array}{l}\text { Sistem akan } \\
\text { menampilkan daftar } \\
\text { lamaran pekerjaan } \\
\text { yang sudah masuk. }\end{array}$ & Berhasil \\
\hline 11 & $\begin{array}{l}\text { Perusahan memilih menu } \\
\text { pengumuman. Kemudian } \\
\text { memilih tombol tambahkan } \\
\text { pengumuman. }\end{array}$ & $\begin{array}{l}\text { Sistem mampu } \\
\text { menambahakan } \\
\text { pengumuman lolos } \\
\text { lowongan. }\end{array}$ & $\begin{array}{l}\text { Sistem akan } \\
\text { menampilkan form } \\
\text { pengumuman. } \\
\text { Kemudian sistem } \\
\text { akan menambahkan } \\
\text { data ke database }\end{array}$ & Berhasil \\
\hline 12 & $\begin{array}{l}\text { Alumni memilih tombol } \\
\text { donwnload pada daftar } \\
\text { engumuman. }\end{array}$ & $\begin{array}{lr}\text { Sistem } & \text { mampu } \\
\text { mengunduh } & \\
\text { pengumuman } & \text { lolos } \\
\text { lowongan } & \\
\end{array}$ & $\begin{array}{ll}\text { Sistem akan } & \text { mendownload } \\
\text { pengumuman } & \\
\text { telah dipilih. } & \\
\end{array}$ & Berhasil \\
\hline 13 & $\begin{array}{lcc}\text { Alumni memilih menu } \\
\text { Online Assessment }\end{array}$ & $\begin{array}{l}\text { Sistem mampu } \\
\text { menampilkan soal TPA }\end{array}$ & $\begin{array}{l}\text { Sistem akan } \\
\text { menampilkan daftar } \\
\text { soal beserta daftar } \\
\text { pilihan jawaban yang } \\
\text { otomatis di generate } \\
\text { secara random. }\end{array}$ & Berhasil \\
\hline 14 & $\begin{array}{l}\text { Admin memilih menu Soal } \\
\text { TPa. Kemudian admin } \\
\text { memilih jenis tipe. Setelah }\end{array}$ & $\begin{array}{lr}\text { Sistem } & \text { mampu } \\
\text { menambahkan } & \text { soal } \\
\text { TPA } & \\
\end{array}$ & $\begin{array}{lr}\text { Sistem akan } \\
\text { menampilkan daftar } \\
\text { jenis soal. Setelah itu }\end{array}$ & Berhasil \\
\hline
\end{tabular}




\begin{tabular}{|c|c|c|c|c|}
\hline & $\begin{array}{lll}\text { itu } & \text { admin } & \text { memilih } \\
\text { tambahkan soal } & \end{array}$ & & \begin{tabular}{lr} 
sistem menampilkan & \multicolumn{1}{r}{} \\
form soal beserta \\
form jawaban. \\
Kemudian sistem \\
akan menambahkan \\
soal ke dalam \\
database.
\end{tabular} & \\
\hline 15 & $\begin{array}{l}\text { Admin memilih tombol } \\
\text { deletepada daftar soal } \\
\text { berdasarkan jenis soal. }\end{array}$ & $\begin{array}{l}\text { Sistem mampu } \\
\text { menghapus soal TPA }\end{array}$ & $\begin{array}{lr}\text { Sistem akan } \\
\text { menghapus soal yang } \\
\text { dipilih dari database. } \\
\text { Kemudian kembali ke } \\
\text { daftar } & \text { soal } \\
\text { berdasarkan } & \text { jenis } \\
\text { soal. } & \\
\end{array}$ & Berhasil \\
\hline 16 & $\begin{array}{ll}\text { Alumni menekan } & \text { tombol } \\
\text { submit } & \text { setelah } \\
\text { mengerjakan. } & \end{array}$ & $\begin{array}{l}\text { Sistem mampu } \\
\text { menghitung nilai TPA }\end{array}$ & $\begin{array}{lr}\text { Sistem } & \text { akan } \\
\text { menghitung jumlah } \\
\text { benar yang akan } \\
\text { diibagi dengan jumlah } \\
\text { soal lalu dikali } 600 \\
\text { ditambah } 200 \text {, } \\
\text { sehingga skor akhir } \\
\text { didapat. }\end{array}$ & Berhasil \\
\hline 17 & $\begin{array}{l}\text { Admin memilih menu } \\
\text { materi. Kemudian admin } \\
\text { memilih tombol tambahkan } \\
\text { materi. }\end{array}$ & $\begin{array}{lr}\text { Sistem } & \text { mampu } \\
\text { menambahkan } & \text { materi } \\
\text { pembekalan } & \end{array}$ & $\begin{array}{lr}\text { Sistem akan } & \text { akampilkan daftar } \\
\text { menampleklan. } \\
\text { materi pembekla } \\
\text { Setelah itu sistem } \\
\text { menampilkan form } \\
\text { materi. Kemudian } \\
\text { data akan ditabahkan } \\
\text { ke dalam database. }\end{array}$ & Berhasil \\
\hline 18 & $\begin{array}{l}\text { Admin atau alumni memilih } \\
\text { menu materi pembekalan. }\end{array}$ & $\begin{array}{lr}\text { Sistem } & \text { mampu } \\
\text { menampilkan } & \text { materi } \\
\text { pembekalan } & \\
\end{array}$ & $\begin{array}{lr}\text { Sistem } & \text { akan } \\
\text { mennampilkan } & \text { daftar } \\
\text { materi. } & \end{array}$ & Berhasil \\
\hline 19 & $\begin{array}{l}\text { Admin memilih menu materi } \\
\text { pembekalan, kemudian. }\end{array}$ & $\begin{array}{l}\text { Sistem } \\
\text { mengedit } \\
\text { pembekalan }\end{array}$ & $\begin{array}{lr}\text { Sistem akan } & \text { menampilkan daftar } \\
\text { materi pembekalan. } \\
\text { Setelah itu sistem } \\
\text { menampilkan form } \\
\text { edit materi. Kemudian } \\
\text { data yang sudah } \\
\text { diperbarui r akan } \\
\text { disimpan ke dalam } \\
\text { sistem }\end{array}$ & Berhasil \\
\hline 20 & $\begin{array}{lrr}\text { Admin memilih } & \text { tombol } \\
\text { hapus didaftar } & \text { materi } \\
\text { pembekalan. } & \end{array}$ & $\begin{array}{l}\text { Sistem } \\
\text { menghapus } \\
\text { pembekalan }\end{array}$ & $\begin{array}{lr}\text { Sistem } & \text { akan } \\
\text { menghapus } & \text { materi } \\
\text { pembekalan yang } & \text { terpilih dari database. }\end{array}$ & Berhasil \\
\hline 21 & $\begin{array}{l}\text { Admin memilih menu berita } \\
\text { kemudian memilih tombol } \\
\text { tambah berita. }\end{array}$ & $\begin{array}{l}\text { Sistem mampu } \\
\text { menambahkan berita }\end{array}$ & $\begin{array}{l}\text { Sistem menampilkan } \\
\text { daftar berita kemudian } \\
\text { menampilkan form } \\
\text { tambah berita. Setelah } \\
\text { itu siatem } \\
\text { menambahkan berita } \\
\text { ke database. }\end{array}$ & Berhasil \\
\hline
\end{tabular}




\begin{tabular}{|c|c|c|c|c|}
\hline 22 & $\begin{array}{l}\text { Admin atau alumni memilih } \\
\text { menu berita. Kemudian } \\
\text { memilih tombol view untuk } \\
\text { menampilkan berita. }\end{array}$ & $\begin{array}{l}\text { Sistem mampu } \\
\text { menampilkan berita }\end{array}$ & $\begin{array}{lr}\text { Sistem } & \text { menampilkan } \\
\text { daftar } & \text { berita. } \\
\text { Kemudian } & \text { sistem } \\
\text { menampilkan } & \text { detail } \\
\text { berita yang } & \text { sudah } \\
\text { dipilih. } & \end{array}$ & Berhasil \\
\hline 23 & $\begin{array}{l}\text { Admin memilih menu berita. } \\
\text { Kemudian memilih tombol } \\
\text { edit dari berita yang } \\
\text { dipilih.setelah mengisi form } \\
\text { edit admin memilih tombol } \\
\text { submit. }\end{array}$ & $\begin{array}{l}\text { Sistem mampu } \\
\text { mengedit berita }\end{array}$ & $\begin{array}{lr}\text { Sistem } & \text { akan } \\
\text { menampilkan daftar } & \text { darian } \\
\text { beritar Kemudian } & \text { sistem akan } \\
\text { menampilkan form } \\
\text { edit berita. Setelah itu } \\
\text { sistem ran } \\
\text { melakukan update } \\
\text { pada berita ke dalam } \\
\text { database. }\end{array}$ & Berhasil \\
\hline 24 & $\begin{array}{l}\text { Admin memilih menu } \\
\text { berita.Kemudian memilih } \\
\text { tombol delete pada salah } \\
\text { saut berita yang terdapat di } \\
\text { daftar berita. }\end{array}$ & $\begin{array}{l}\text { Sistem mampu } \\
\text { menghapus berita }\end{array}$ & $\begin{array}{l}\text { Sistem menampilkan } \\
\text { daftar berita. Setelah } \\
\text { itu sistem akan } \\
\text { menghapus berita } \\
\text { yang telah diilih oleh } \\
\text { admin dari database. }\end{array}$ & Berhasil \\
\hline 25 & $\begin{array}{l}\text { Alumni memilih menu profil. } \\
\text { Setelah itu alumni memilih } \\
\text { tombol edit data pada form } \\
\text { biodata alumni yang dipilih. }\end{array}$ & 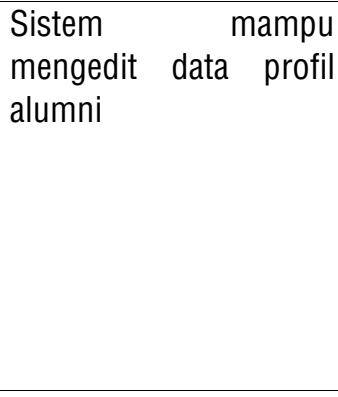 & \begin{tabular}{lr} 
Sistem menampilkan \\
daftar biodata alumni. \\
Setelah salsah satu \\
form dipilih maka \\
sistem akan \\
menampilkan form \\
edit.Setelah itu sistem \\
akan melakukan \\
\multicolumn{2}{l}{ update pada database. }
\end{tabular} & Berhasil \\
\hline 26 & Alumni memilih menu profil. & $\begin{array}{lr}\text { Sistem } & \text { mampu } \\
\text { menampilkan } & \text { data } \\
\text { profil alumni } & \end{array}$ & $\begin{array}{lr}\text { Sistem } & \text { akan } \\
\text { menapilkan } & \text { biodata } \\
\text { alumni. } & \end{array}$ & Berhasil \\
\hline
\end{tabular}

Dalam Sistem Informasi Career Development Center Fakultas Matematika dan IImu Pengetahuan Alam Universitas Sebelas Maret surakarta terdapat fitur online asssessment Tes Potensial Akademik dimana untuk hasil penilaian dari soal tes potensial akademik tersebut menggunakan rumus perhitungan BAPPENAS sebagai berikut: Skor TPA = (jumlah benar / jumlah total soal $\times 600)+200$.

\section{KESIMPULAN}

Kesimpulan yang dapat diambil berdasarkan pembahasan diatas yaitu telah dibuat sistem informasi career development centre FMIPA UNS. Berdasarkan hasil pengujian sistem, fungsionalitas sistem dapat berjalan dengan baik. Fungsionalitas tersebut antara lain mengelola data lowongan, mengelola data pengumuman lowongan, mengelola data alumni dan perusahaan, serta mengelola online assessment. 


\section{DAFTAR PUSTAKA}

[1] Hendrawan, Andika and Dewanto, Joko, "Pengembangan Sistem Career Centre Untuk Departemen Konseling Dan Pengembangan Karir (DKPK) Universitas ESA Unggul”, Jurnal IImu Komputer. vol.9. 2013.

[2] Kusmiati, Herlinda, "Pengembangan Sistem Informasi Bursa Lowongan Pekerjaan Divisi Career Center Palcomtech Berbasis WEB", Jurnal IImu Komputer. vol.5, pp. 35-49. 2015.

[3] Hermawan J, Somantri M., and Satoto K.(2012) Perancangan Career Development Center Undip Berbasis Web[online].Available : http://eprints.undip.ac.id/32528/.

[4] Stefanny, Vanessa and Nurasia, "Analisa Dan Perancangan Aplikasi Career Development Center Pada STIMIK Insan Pembangunan", Jurnal IPSIKOM. vol.5. 2017.

[5] Syahputra, Arma and Kusuma H, "Pengembangan Sistem Cereer Center Untuk departemen Konseling Dan Pengembangan Karir Di Institut Teknologi Budi Utomo", Jurnal BSI. vol.3. 2015.

[6] Laplante, Philip and Colin, Neil, "The Demise of the Waterfall Model Is Imminent' and Other Urban Myths", ACM Queue. 2008. 